\title{
PHOTOCATALYTIC ACTIVITY OF Ce-DOPED ZnO NANOPARTICLES
}

\author{
FOTOKATALITIČNA AKTIVNOST S Ce DOPIRANIH ZnO \\ NANODELCEV
}

\author{
Chengyou Liu', Jinghua $\mathrm{Xu}^{2}$, Su $\mathrm{Cui}^{2}$, Hai $\mathrm{Yu}^{2}$ \\ 1Institute of Chemistry and Materials, Hainan Institute of Science and Technology, Hannan 570100, China \\ ${ }^{2}$ Department of Physics, Tonghua Normal University, Tonghua, Jilin, China \\ 13943599862@163.com
}

Prejem rokopisa - received: 2017-11-03; sprejem za objavo - accepted for publication: 2017-11-23

doi:10.17222/mit.2017.188

\begin{abstract}
Semiconductor materials are often used as photocatalysts. In order to increase the photocatalytic ability, rare earths are usually added to change the properties of materials. In this paper, we report that $\mathrm{Ce}: \mathrm{ZnO}$ nanoparticles were synthesized and their photocatalytic properties researched. Wastewater containing methyl blue was used as the object of investigation. Ce:ZnO samples were synthesized using a simple chemical method. Four samples were obtained: three containing Ce concentrations of $(1,2$ and 3$) \%(w / \%)$ and one of pure ZnO. Optical properties of the samples were investigated with UV-Vis. X-ray diffraction (XRD) and field-emission scanning electronic microscopy (FESEM) were employed to examine the chemical composition and microstructures. It was found that the size of $\mathrm{ZnO}$ crystallites is suppressed after Ce-doping. Further, the samples were used as efficient photocatalysts for a photocatalytic degradation of methyl blue. It was observed that Ce-doped $\mathrm{ZnO}$ nanoparticles exhibited excellent photocatalytic properties. The degradation ability increased with the increasing Ce concentration. For the sample of $3 \%$ of mass fractions of Ce-doped $\mathrm{ZnO}$, a complete photodegradation was observed after $60 \mathrm{~min}$.
\end{abstract}

Keywords: Ce-doped $\mathrm{ZnO}$, nanoparticles, photocatalyst, methyl blue, photodegradation

Polprevodniki se pogosto uporabljajo kot fotokatalizatorji. Povečanje katalitične sposobnosti dosežemo tako, da materialom dodamo elemente redkih zemelj in s tem spremenimo njihove lastnosti. V tem članku avtorji poročajo o sintezi nanodelcev ZnO z dodatkom cerija (Ce) in raziskavi njihovih fotokatalitičnih lastnosti. Kot predmet raziskovanja so izbrali odpadno vodo, ki je vsebovala metilensko modrilo. Vzorce Ce:ZnO so sintetizirali z enostavno kemijsko metodo. Izdelali so štiri vzorce; čisti ZnO, in tri vzorce, ki so vsebovali $(1,2$, in 3) \% masnih deležev Ce. Optične lastnosti vzorcev so določili s spektroskopijo, ki temelji na absorpciji ultravijolične in vidne svetlobe (UV-Vis). Za določitev kemijske sestave in mikrostrukture pa so uporabili rentgensko difrakcijo (XRD) in vrstično elektronsko mikroskopijo na emisijo polja (FESEM). Avtorji članka so ugotovili, da je rast $\mathrm{ZnO}$ kristalitov zavrta po dopiranju s Ce. Nadalje so vzorce učinkovito uporabili kot fotokatalizatorje za fotokatalitično degradacijo metilenskega modrila. Ugotovili so da imajo s cerijem dopirani nanodelci ZnO odlične fotokatalitične lastnosti. Stopnja degradacije se je povečevala s povečevanjem koncentracije Ce. Pri vzorcu nanodelcev $\mathrm{ZnO}$ s 3 mas. \% dodatkom Ce je prišlo do popolne degradacije po 60 minutah.

Ključne besede: s Ce dopiran $\mathrm{ZnO}$, nanodelci, fotokatalizator, metilensko modrilo, fotodegradacija

\section{INTRODUCTION}

Environmental pollution has become a world problem. At the international level, the governments and people pay more attention to our environment. With the development of science and technology, it became more important to protect our environment. Among environmental challenges, the most serious problems are the water and air pollution. With the development of modern agriculture and industry, more and more wastewater is poured into rivers, lakes and fields. The rivers are becoming so dirty that no living beings can live in it. The water is giving off a terrible smell, which is a threat to people's safety. Due to containing a large number of organic and inorganic compounds, wastewater has caused serious pollution in the world, especially in the developing countries. The pollution can harm crops, cause various diseases, such as digestive-system disease, respiratory disease, cardio-cerebrovascular disease, heavy-metal overdose, calculus, etc. Finding ways to protect our water from pollution has been one of the most difficult problems in the world. We must accept that, due to society development, we daily produce wastewater, polluting the waters. So, it is very important to control water pollution and purify wastewater.

Up to now, nano-semiconductor oxides such as $\mathrm{TiO} 2$ and $\mathrm{ZnO}$ have been given a lot of attention in the field of photocatalysis. ${ }^{1-6}$ Their photocatalytic ability to degrade organic pollutants in water and air were widely studied. Both of them have many advantages such as a strong oxidation power, chemical inertness and stability against chemical corrosion and photocorrosion..$^{7-12}$

For the past few years, $\mathrm{ZnO}$ has been a hot academic topic. Due to its excellent optical and electrical properties, large band gap (3.37 eV) and exciton energy $(60 \mathrm{MeV}), \mathrm{ZnO}$ is expected to be important in applications such as sensing, light-emitting diodes, photocatalysts, solar cells and transparent conducting layers. ${ }^{13-17}$ As we know, the photocatalytic efficiency is relative to the surface chemical reaction and electron- 
hole recombination. If the course of electron-hole recombination is too fast, the surface chemical reaction will not occur. The photocatalytic efficiency will be low. So, finding a way to restrain electron-hole recombination is the key to increasing the photocatalytic efficiency.

In order to improve optical, electronic and magnetic properties, multiple elements are doped into $\mathrm{ZnO}$ to form a ternary or a multicomponent. After doping, the band gap, electron mobility and photocurrent response are greatly changed. To achieve these changes, the rare earth $\mathrm{Ce}$ doped into $\mathrm{ZnO}$ to get a $\mathrm{Ce}_{\mathrm{x}} \mathrm{Zn}_{1-x} \mathrm{O}$ ternary is widely researched and used. When Ce-doped $\mathrm{ZnO}$ is used in a photocatalytic study, increasing the photocatalytic efficiency is a problem that must be solved urgently. ${ }^{18,19}$

In this paper, we report on our research work including the synthesis of pure and $\mathrm{Ce}$-doped $\mathrm{ZnO}$ nanomaterials with different concentrations of $\mathrm{Ce}$, and on a photocatalytic experiment. The photocatalytic-efficiency dependence on the Ce-concentration was studied.

\section{EXPERIMENT}

Ce-doped $\mathrm{ZnO}$ samples were synthesized using a simple chemical-precipitation method. ${ }^{20}$ In brief, zinc nitrate hexahydrate $\left(\mathrm{Zn}\left(\mathrm{NO}_{3}\right)_{2} \cdot 6 \mathrm{H}_{2} \mathrm{O}\right)$ and ammonium bicarbonate $\left(\mathrm{NH}_{4} \mathrm{HCO}_{3}\right)$ were chosen as the starting material and cerium nitrate hexahydrate $\left(\mathrm{Ce}\left(\mathrm{NO}_{3}\right)_{3} \cdot 6 \mathrm{H}_{2} \mathrm{O}\right)$ was used as the dopant source. Deionized water was used as the solvent. All the analytical-grade reagents were purchased from Sinopharm Chemical Regent Co., Ltd., without further purification. The synthesis method was as follows: first, $\mathrm{Zn}\left(\mathrm{NO}_{3}\right)_{2} \cdot 6 \mathrm{H}_{2} \mathrm{O}$ and $\mathrm{Ce}\left(\mathrm{NO}_{3}\right)_{3} \cdot 6 \mathrm{H}_{2} \mathrm{O}$ were dissolved in deionized water with a molar ratio of $\mathrm{Ce} /(\mathrm{Ce}+\mathrm{Zn})$ being $\mathrm{x}: 1(x=0.00,0.01,0.02$ and 0.03$)$. Second, the amounts of the $\mathrm{NH}_{4} \mathrm{HCO}_{3}$ aqueous solution were transferred into the $\mathrm{ZnO} / \mathrm{Ce}$ aqueous solution during constant stirring. Then, white precipitates were formed in the above mixture solution and washed with deionized water and alcohol for several times. After having been dried in an oven at $60{ }^{\circ} \mathrm{C}$ for several hours, the white precipitates were finally annealed under air atmosphere for $3 \mathrm{~h}$ at $450{ }^{\circ} \mathrm{C}$.

An X-ray diffractometer (XRD, D/Max-2400) was used to analyze the crystal structures of synthesized

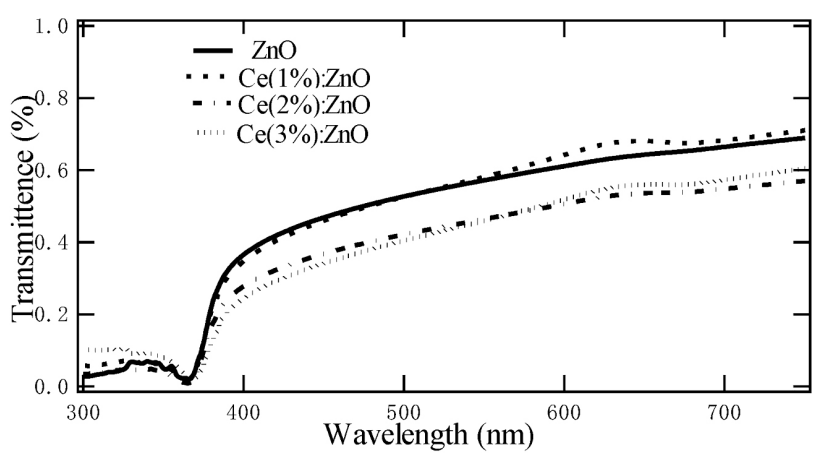

Figure 1: Transmittance spectra of the Ce: $\mathrm{ZnO}$ nanoparticles nanoparticles. The morphology was investigated with a field scanning electron microscope (FSEM, S-4800). Optical properties of the samples were studied by measuring the transmittance in a range of 300-800 nm. The photocatalytic activity of the light-degraded methyl blue was investigated.

Experimental details of the photocatalysis are as follows: $100 \mathrm{~mL}$ of wastewater containing methyl blue was poured into a $200-\mathrm{mL}$ breaker. The concentration of methyl blue was $40 \mathrm{mg} / \mathrm{L} .10 \mathrm{mg}$ of Ce-doped $\mathrm{ZnO}$ nanoparticles with different $\mathrm{Ce}$ molar ratios $(\mathrm{Ce} /(\mathrm{Ce}+\mathrm{Zn})$ was $\mathrm{x}: 1(\mathrm{x}=0.00,0.01,0.02$ and 0.03$))$ were put into the wastewater solution. All the samples were dispersed under magnetic stirring for $10 \mathrm{~min}$. A 15-watt UV lamp was used as the excitation light source, fixed $15 \mathrm{~cm}$ above the treated solution. The decay of methyl blue was monitored with UV-Vis absorbance measurements, made at intervals of $20 \mathrm{~min}$. All of the experiments were carried out against a dark background and at room temperature.

The photocatalytic efficiency can be characterized with photodegradation percentage defined as \#, where $\mathrm{A}_{0}$ and $\mathrm{A}$ are the initial concentration and the concentration obtained over a period of time, respectively. According to the Beer Law, the concentration can be expressed with absorbance.

\section{RESULTS AND DISCUSSION}

The absorption spectra of a sample were measured at room temperature in the range of $300-800 \mathrm{~nm}$. The result is shown in Figure 1. The sample exhibited high transmittance in the visible regions. With the increasing Ce concentration, the absorption edge of the sample moved slightly to the lower-energy direction. However, as the $\mathrm{Ce}$ concentration changed only slightly, the valence band of the sample could not be changed too much. For our samples, the experimentally measured valence-band gap is about $3.36 \mathrm{eV}$. The result is similar to the report of Varughese et al. ${ }^{21}$

The XRD patters of the samples are shown in Figure 2. It was found that all the diffraction peaks of $\mathrm{ZnO}$

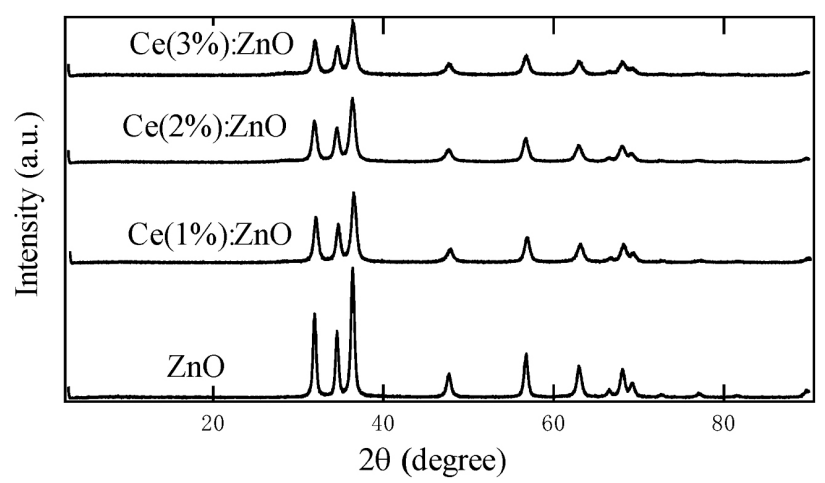

Figure 2: XRD patterns of the Ce:Zno nanoparticles with Ce concentrations of $(0,1,2$ and 3$) \%$ 
and $\mathrm{Ce}: \mathrm{ZnO}$ can be indexed as a hexagonal wurtzite structure, without the characteristic peaks for the other impurities.

The intensity of diffraction peaks decreases with the increasing concentration of $\mathrm{Ce}$. The half-width of a peak becomes wider when the concentration of $\mathrm{Ce}$ increases. Besides, the positions of the corresponding diffraction peaks of Ce-doped $\mathrm{ZnO}$ shift slightly toward the lower angle.

This phenomenon can be explained as follows: due to the fact that $\mathrm{Ce}^{4+}(0.092 \mathrm{~nm})$ and $\mathrm{Ce}^{3+}(0.103 \mathrm{~nm})$ are a bit larger than $\mathrm{Zn}^{2+}(0.074 \mathrm{~nm})$, this shift of diffraction peaks indicates that the Ce ions were incorporated into the $\mathrm{ZnO}$ lattice, substituting the $\mathrm{Zn}$ ion sites. The information about the lattice constants of pure and Ce-doped $\mathrm{ZnO}$ obtained from the XRD data can be calculated using the Scherrer formula, $D=0.89 \lambda /(\beta \cdot \cos \theta)$, where $\lambda=0.154056 \mathrm{~nm}$ at the $\mathrm{Cu} K_{\alpha 1}$ radiation, $\beta$ is the halfwidth of the diffraction peak and $\theta$ is the Bragg angle.

In our case, the crystallite size is estimated to be about $35-50 \mathrm{~nm}$. It is found that the crystallite size decreases with the increasing Ce concentration. This can be explained as follows: In the course of the crystallite growth, the particle size is dependent on the particle boundary motion. When increasing the Ce concentration, the lattice agglomerates and the distortion caused by the addition of Ce decreases the particle mobility and, therefore, inhibits the growth of the $\mathrm{ZnO}$ crystallites.

The morphology of pure and Ce-doped $\mathrm{ZnO}$ was observed with FSEM. The images of pure and Ce-doped $\mathrm{ZnO}$ are shown in Figure 3. The usual nanoparticles with a diameter of about 35-50 nm (Figure 3) were observed, which accords with the results calculated from the XRD data.

It was found that the size of nanoparticles decreases with the increasing Ce concentration.

The absorbance changes of methyl blue with the UV irradiation time are shown in Figure 4.
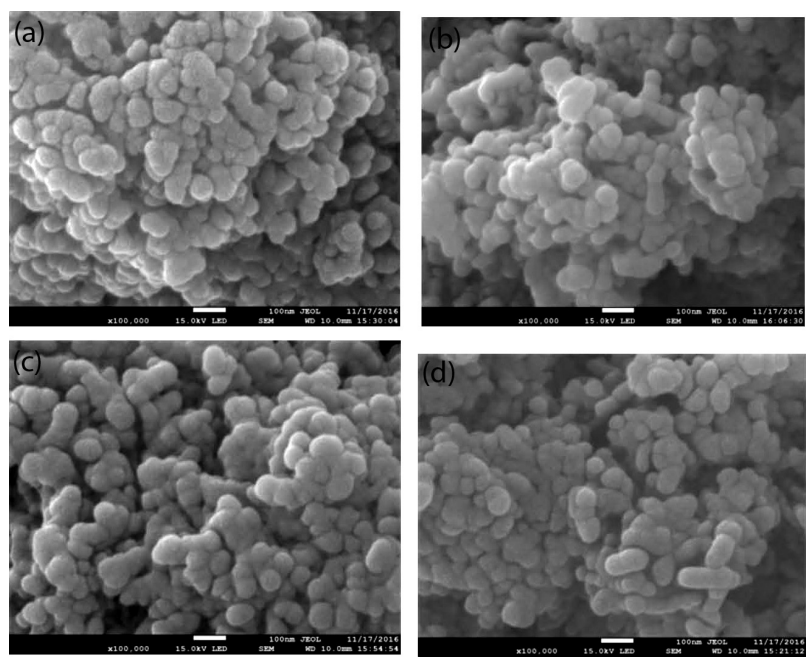

Figure 3: FSEM images of Ce-doped $\mathrm{ZnO}$, Ce concentrations of: a) $0 \%$, b) $1 \%$, c) $2 \%$ and d) $3 \%$
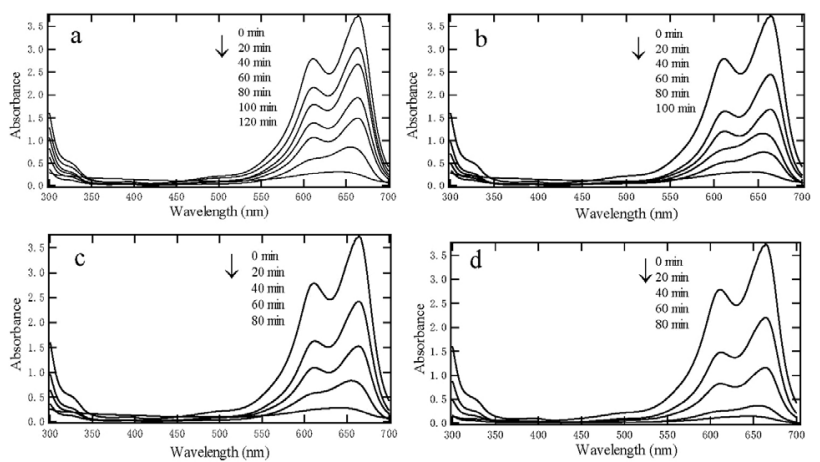

Figure 4: Absorbance changes of methyl blue with UV irradiation time for: a) pure $\mathrm{ZnO}$, b) $1 \% \mathrm{Ce}$, c) $2 \% \mathrm{Ce}$ and d) $3 \% \mathrm{Ce}: \mathrm{ZnO}$ nanoparticles as the photocatalysts

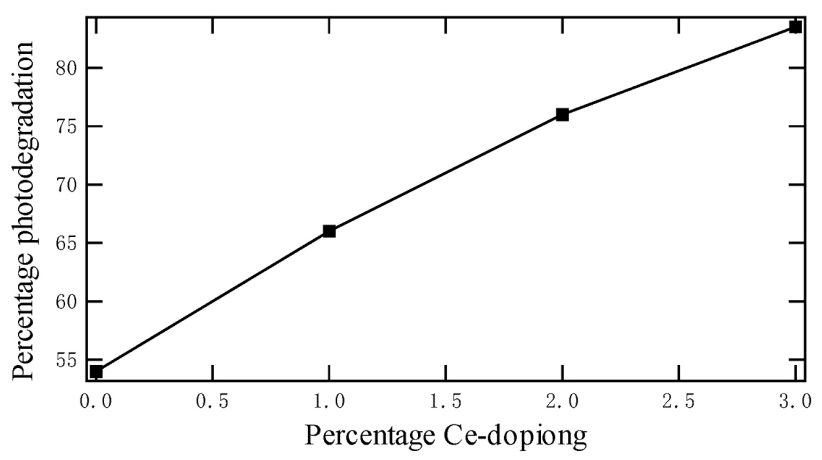

Figure 5: Percentage of photodegradation vs Ce-doping after $60 \mathrm{~min}$ of UV irradiation

The absorption band at a wavelength of about $650 \mathrm{~nm}$ decreases with the increasing irradiation time for all the Ce-doped $\mathrm{ZnO}$ photocatalysts. After about $80 \mathrm{~min}$ of UV irradiation, a complete photodegradation is observed for the $\mathrm{Ce}(3 \%)$ doped $\mathrm{ZnO}$ sample. After $60 \mathrm{~min}$ of UV irradiation, the percentage of the photodegradation of methyl blue was measured for the four samples. The result is shown in Figure 5. It is very clear that the photocatalytic effect increases with the increasing $\mathrm{Ce}$ concentration.

Using the $650-\mathrm{nm}$ absorption intensity related to the concentration of methylene blue, variations $\mathrm{A}_{0}$ and $\mathrm{A}$ versus the irradiation time are shown in Figure 6.

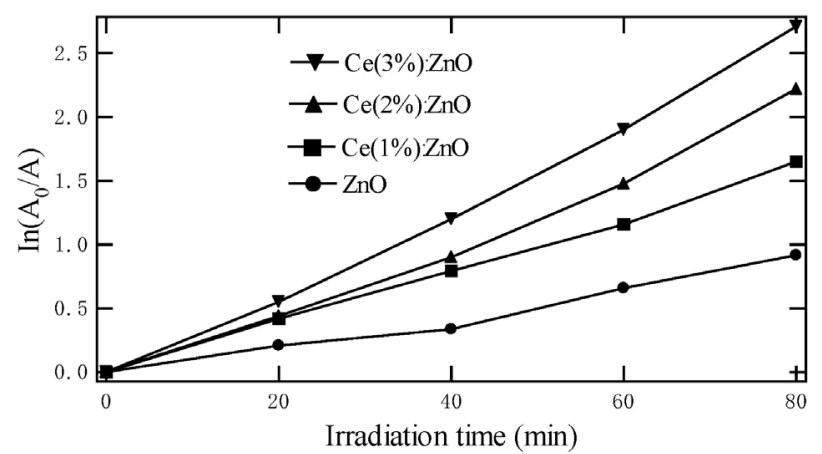

Figure 6: $\mathrm{A} 0 / \mathrm{A}$ as a function of irradiation time for methyl blue photodegradation using $\mathrm{Ce}: \mathrm{ZnO}$ as the photocatalyst 


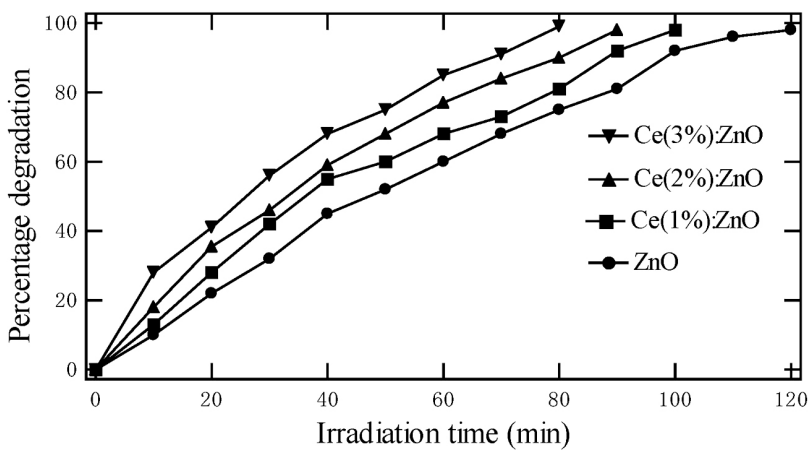

Figure 7: Percentage of photoabsorbance of methylene blue with Ce-doped $\mathrm{ZnO}$ samples vs UV irradiation time

The variation in the percentage of photodegradation of methyl blue with irradiation time was investigated and shown in Figure 7.

The experimental results show that the absorbance of methyl-blue solution decreases with the increasing UV irradiation time. It takes about $120 \mathrm{~min}$ for $\mathrm{ZnO}$ to become completely photodegraded. However, for the $\mathrm{Ce}$-doped $\mathrm{ZnO}$ samples, the time of complete photodegradation reduces to $98 \mathrm{~min}(1 \% \mathrm{Ce}), 85 \mathrm{~min}(2 \%$ $\mathrm{Ce})$ and $75 \min (3 \% \mathrm{Ce})$.

The experiments prove that $\mathrm{Ce}$-doped $\mathrm{ZnO}$ improves the photocatalytic ability. As we know, the mechanism of photocatalysis is based on the migration of electrons and holes to the surfaces of catalytic nanoparticles upon an UV irradiation and their subsequent participation in a redox reaction with the adsorbed methylene blue in the solution. The reason for enhanced photocatalysis can be explained as follows: Firstly, when the $\mathrm{Ce}^{4+}$ ions are doped into the $\mathrm{ZnO}$ lattice, the $\mathrm{Zn}$ site is replaced by $\mathrm{Ce}^{4+}$ to form electron-donor defects. In order to maintain electronic neutrality, Ce ions must release electrons into the conduction band, which increases the concentration of free electrons. Hence, the increased transport of electrons results in a higher response. Secondly, $\mathrm{Ce}^{4+}$ can also trap the conduction-band electrons to eliminate or reduce the probability of electron-hole recombination. Thirdly, the oxygen vacancy after doping Ce on photolytic surfaces can serve as a trap for the electrons from the conduction band. Fourthly, because $\mathrm{Ce}^{4+}$ ion radius is larger than that of $\mathrm{Zn}^{+}$, the average crystalline of $\mathrm{Ce}$-doped $\mathrm{ZnO}$ is smaller than that of pure $\mathrm{ZnO}$. This makes the specific surface increase and provide for more active centers for oxygen molecules adsorbed on the surface, which increases the electron transport. All of these can efficiently enhance the transfer of photogenerated electrons to participate in the redox reaction, forming $\mathrm{OH}$ free radicals causing methylene-blue degradation.

\section{CONCLUSION}

Pure $\mathrm{ZnO}$ and various $\mathrm{Ce}: \mathrm{ZnO}$ samples were prepared with a simple chemical-precipitation method. The results of XRD and FESEM clearly revealed the microstructures of the samples with a size of about 35-80 nm. Using methylene blue as the reactant, photocatalytic properties of $\mathrm{ZnO}$ and Ce-doped $\mathrm{ZnO}$ were investigated. The experimental results show that Ce-doped $\mathrm{ZnO}$ is more photocatalytically active than pure $\mathrm{ZnO}$. The ability of photodegradation increases with the increasing $\mathrm{Ce}$ concentration. For pure $\mathrm{ZnO}$ and $3 \%$ Ce-doped $\mathrm{ZnO}$, a complete degradation was observed in $120 \mathrm{~min}$ and $75 \mathrm{~min}$, respectively. Furthermore, this work implies that suitable Ce-doping can improve the photocatalytic ability of a $\mathrm{ZnO}$ NP-based photocatalyst. Moreover, more research will be carried out within our forthcoming work.

\section{REFERENCES}

${ }^{1}$ O. Carp, C. L. Huisman, A. Reller, Photoinduced Reactivity of Titanium Dioxide, Progress in Solid State Chemistry, 32 (2004) 1-2, doi:10.1016/j.progsolidstchem.2004.08.001

${ }^{2}$ A. Umar, Y. B. Hahn, Metal Oxide Nanomaterials and Their Applications, Vol. 1-5, American Scientific Publishers, Los Angeles, YSA, 2010

${ }^{3}$ Z. Liu, C. Liu, J. Ya, E. Lei, Controlled synthesis of $\mathrm{ZnO}$ and $\mathrm{TiO} 2$ nanotubes by chemical method and their application in dye-sensitized solar cells, Renew. Energy, 36 (2011), doi:10.1016/j.renene. 2010.09.019

${ }^{4}$ H. X. Chen, H. Yu, S. Cui, H. J. Xu, Y. Zhang, C. Y. Liu, Synthesis of $\mathrm{Ce}: \mathrm{ZnO}$ nanocomposites: Facile synthesis and fast acetone gas sensing response properties, Physica B: Condensed Matter, 516 (2017), doi:10.1016/j.physb.2017.04.018

${ }^{5}$ W. E. Mahmoud, Synthesis and optical properties of Ce-doped $\mathrm{ZnO}$ hexagonal nanoplatelets, Journal of Crystal Growth, 312 (2010) 21, doi:10.1016/j.crysgro.2010.07.040.

${ }^{6}$ R. P. Souza, T. K. F. S. Freitas, F. S. Domingues, O. Pezoti, E. Ambrosio, A. M. Ferrari-Lima, J. C. Garcia, Photocatalytic activity of $\mathrm{Ti}_{\mathrm{O} 2}, \mathrm{ZnO}$ and $\mathrm{N}_{\mathrm{b} 2 \mathrm{O} 5}$ applied to degradation of textile wastewater, Journal of Photochemistry and Photobiology A: Chemistry, 329 (2016) 1, doi:10.1016/j.jphotochem. 2016.06.013

${ }^{7}$ R. Kumar, A. Umar, G. Kumar, M. S. Akhtar, Y. Wang, S. H. Kim, $\mathrm{Ce}$-doped $\mathrm{ZnO}$ nanoparticles for efficient photocatalytic degradation of direct red-23 dye, Ceramics International, 41 (2015), doi:10.1016/j.ceramint.2015. 02. 110

${ }^{8}$ G. Kumar, R. Kumar, S. W. Hwang, A. Umar, Photocatalytic degradation of direct red-23 dye with $\mathrm{ZnO}$ nanoparticles, J. Nanosci. Nanotechnol., 14 (2014), doi:10.1166/jnn. 2014. 9229

${ }^{9}$ A. Fujishima, T. N. Rao, D. A. Tryk, Titanium dioxide photocatalysis, J. Photochem. Photobiol. C, 1 (2000), 1-21, doi:10.1016/ S1389-5567(00)00002-2

${ }^{10}$ H. Choi, A. Sofranko, D. Dionysiou, Nanocrystalline TiO2 photocatalytic membranes with a hierarchical mesoporous multilayer structure: synthesis, characterization, and multifunction, Advanced Functional Materials, 16 (2010) 8, doi:10.1002/adfm.200500658

${ }^{11}$ C. Karunakaran, P. Gomathisankar, G. Manikandan, Preparation and characterization of antimicrobial $\mathrm{Ce}$-doped $\mathrm{ZnO}$ nanoparticles for photocatalytic detoxification of cyanide, Materials Chemistry and Physics, 123 (2010) 2-3, doi:10.1016/j.matchemphys.2010.05.019

${ }^{12}$ R. P. Souza, T. K. F. S. Freitas, F. S. Domingues, O. Pezoti, E. Ambrosio, A. M. Ferrari-Lima, J. C. Garcia, Photocatalytic activity of $\mathrm{TiO}_{2}, \mathrm{ZnO}$ and $\mathrm{Nb}_{2} \mathrm{O}_{5}$ applied to degradation of textile wastewater, Journal of Photochemistry and Photobiology A: Chemistry, 329 (2016) 1, doi:10.1016/j.jphotochem.2016.06.013 
${ }^{13}$ J. Xu, J. Han, Y. Zhang, Y. Sun, B. Xie, Studies on alcohol sensing mechanism of $\mathrm{ZnO}$ based gas sensors, Sensors and Actuators, B Chemical, 132 (2008) 1, doi:10.1016/j.snb.2008.01.062

${ }^{14}$ M. C. Jeong, B. Y. Oh, M. H. Ham, S. W. Lee, J. M. Myoung, $\mathrm{ZnO}$-nanowire-inserted $\mathrm{GaN} / \mathrm{ZnO}$ heterojunction light-emitting diodes, Small, 3 (2007) 4, doi:10.1002/smll.200600479

${ }^{15}$ R. Kumar, G. Kumar, A. Umar, $\mathrm{ZnO}$ nano-mushrooms for photocatalytic degradation of methyl orange, Mater. Lett., 97 (2013), doi:10.1016/j.matlet.2013.01.004

${ }^{16}$ J. A. Anta, E. Guillén, R. Tena-Zaera, ZnO-Based Dye-Sensitized Solar Cells, J. Phys. Chem. C, 116 (2012) 21, 11413-11425, doi:10.1021/jp3010025

${ }^{17}$ D. J. Kwaka, J. H. Kima, B. W. Parka, Y. M. Sunga, M. W. Park, Y. B. Choo, Growth of $\mathrm{ZnO}$ :Al transparent conducting layer on polymer substrate for flexible film typed dye-sensitized solar cell, Current Applied Physics, 10 (2010) 2, Supplement, doi:10.1016/j.cap.2009. 11.063
${ }^{18}$ M. Ahmad, E. Ahmed, F. Zafar, N. R. Khalid, N. A. Niaz, A. Hafeez, M. Ikram, M. Ajmal, M. Ajimal Khan, Z. L. Zhang, Enhanced photocatalytic activity of Ce-doped $\mathrm{ZnO}$ nanopowers synthesized by combustion method, Journal of Rare Earths, 33 (2015) 3, doi:10.1016/S1002-0721(14)60412-9

${ }^{19}$ C. J. Chang, C. Y. Lin, M. H. Hsu, Enhanced photocatalytic activity of Ce-doped $\mathrm{ZnO}$ nanorods under UV and visible light, Journal of the Taiwan Institute of Chemical Engineers, 45 (2014), doi:10.1016/ j.jtice.2014.03.008

${ }^{20}$ J. H. Lang, Q. Han, J. H. Yang, C. S. Li, X. Li, L. L. Yang, Y. J. Zhang, M. Gao, D. D. Wang, J. Cao, Fabrication and Optical Properties of Ce-Doped ZnO Nanorods, Journal of Applied Physics, 107 (2010), 074302. doi:10.1063/1.3318613

${ }^{21}$ G. Varughese, P. W. Jithin, K. T. Usha, Determination of Optical Band Gap Energy of Wurtzite ZnO: Ce Nanocrystallites, Physical Science International Journal, 5 (2015) 2, stacks.iop.org/JPhysCM/ 20/075233 